\title{
Representation of Optimism in the Contemporary Advertising: Gojek "Cerdikiawan"
}

\author{
Fikry Zahria Emeraldien ${ }^{1}$, Natasya Candraditya $S^{2}$, \\ Amalia Farahdiba ${ }^{2}$, Ramadhoni Cahya C. W ${ }^{2}$ \\ ${ }^{1}$ Department of Social Science, Faculty of Social Science and Political Science, Universitas Airlangga \\ ${ }^{2}$ Department of Communication Science, Faculty of Social Science and Political Science \\ UPN "Veteran" Jawa Timur \\ Corresponding Author’s Email: fikryemeraldien@gmail.com
}

\begin{abstract}
Creativity of an advertisement in building public perception is something that ad producers often do to promote their products or services to attract many interested people. However, contemporary advertising production began to experience a shift. In the past, advertisements generally used the hard selling method; but now they have changed to soft selling, which do not to introduce or sell their products directly. Contemporary advertising often represent audiences and things that are close to daily life, for example Gojek "Cerdikiawan" \#pastiadajalan advertising. Thus, this research is interested in studying that advertisement. We tried to peel one by one of the signs that exist in Gojek "Cerdikiawan". The method used is qualitative with Roland Barthes' semiotics analysis. This study aims to determine the representation of optimism in advertising and identify the meanings of denotation, connotation, and myth displayed by Gojek "Cerdikiawan". The discussion of this research includes visible visual elements and also the narrative voice of the advertisement. This study conclude that the meaning of denotation and connotation gives rise to a perception which is an ideology that ad producers want to display. Ideology contained in this advertisement is the optimism, which is shown in each scene. It is a representation of all groups of people and their daily lives which are full of challenges. The ad also represents that every problem can definitely be solved in a way that might not be thought of, with creative ideas, and with an optimistic attitude of the people. Gojek "Cerdikiawan" is an advertising in the form of soft selling with a fairly long duration packed with interesting stories.
\end{abstract}

Keywords: soft selling, advertising, semiotics, representation, reality construction, optimism 


\section{INTRODUCTION}

One tool to promote a product or service is to use advertisements. Advertising is always available in the community, although sometimes without us knowing. Advertising uses every medium that allows to convey its message. This can be done through mass media both electronic and print. Companies, in reaching a wide audience, often use mass media to show their existence to the public. Electronic mass media displaying 24 hour shows accompanied by attractive advertisements. To create an effective advertisement, creativity is needed in the content displayed.

In the academic world, advertising can be studied in various points of view or fields, for example marketing and communication. Kim et al (2014) have examined the trends of various studies on advertising for 30 years, 1980 to 2010. One result is that advertising is often associated with communication.

More specifically, representation studies are often used to research advertising. In Indonesia, there have been many communication scholars who have researched advertising using representations. An example is Hasyim, M. (2014) who examines the Construction of Myths and Ideologies in Television Commercial Advertising Texts: A Semiological Analysis for his dissertation. There is also Yuliyanti, F. D., Bajari, A., \& Mulyana, S. (2017) who examined the Representation of Masculinity in the Pond's Men \#Lelakimasakini Television Advertising (Roland Bathers Semiotic Analysis of Representation of Masculinity). In addition, there is also Lago, M. N. (2017) with her journal article entitled Exploitation of the Female Body in Television Media (Semiotic Analysis Meaning of Advertising Message of Avian Syntetic Paint Wet Paint Version).

When viewed from the themes above, the advertising representations studied were mostly related to gender. Meanwhile, studies of advertising representation related to optimism are still rare. In fact, it is an important thing, because having an element of novelty shows a trend that is happening among young people today. For example, can be seen in the research have Nugroho, Y.K, \& Hamzah, R. E. (2018).

The younger generation tends to be formed into a generation of spectators and consumers. Adopting a millennial theme is a lot done by the advertising industry. This is because the public will easily accept or easily interpret a message and meaning if it is close to his life.

Millennials have become one of the causes of shifts in advertising strategies that were previously intensified by hard selling and turned into soft selling. The pattern of life of a consumptive urban society influences the creativity of advertising creation. Likewise, contemporary or current advertising is more directed towards soft selling.

One of the latest and very important trends in contemporary advertising is goodvertising, i.e. the inclination of brands to communicate about topics of goodness for the whole of society, and even on social change. Those topics are not directly related to their business strategies in the strict sense of the term. The companies, corporations and business people behind these brands are making their advertising say that they are 
interested in something more than just sales curves. Goodvertising expresses a new type of marketing and branding: cause marketing and "brands that care".

Soft selling advertisements that display products or services have implied or explicit meanings. The representation of advertisements that use themes close to daily life raises meanings and perceptions for the audience. For this reason, we will discuss how the "Cerdikiawan" Gojek advertisement, which can be said as a soft selling ad, represents an attitude of optimism.

\section{LITERATURE REVIEW}

Referring to the Association of Indonesian Advertising Companies (P31), advertising is any form of message about a product delivered through a media, funded by a recognized proponent, and addressed to some or all of the community. Advertising as a form of marketing communication must basically be able to inform marketing objectives to the target audience by focusing on good values. According to Kotler (2000), advertising as a form of presentation and promotion of ideas, goods or services on a non-personal basis by a particular sponsor that requires payment.

Meanwhile, according to Ubaedy (2007), optimism has two meanings. First is the life doctrine that teaches us to believe in a better life. Second, optimism means an inner tendency to plan actions, to achieve better results or to believe in a better life and that belief we make as provisions to achieve better results. According to Segerestrom (in Ghufron and Risnawati, 2010) optimism is a positive and realistic way of thinking in looking at a problem.

Seligman (in Ghufron and Risnawati, 2010) states that optimism is a holistic view, sees good things, thinks positively, and easily gives meaning to oneself. According to KBBI, optimism is the understanding or belief in everything in terms of good and pleasant. This word also means attitude always has good expectations in everything.

In advertising, optimism is a construction, which is a social process through actions and interactions in which individuals (or groups of individuals) create continuously a reality that is shared and experienced together subjectively (Charles R. Ngangi, 2011). All forms of social reality, including media content, are realities that are deliberately constructed. Berger and Luckman say that community institutions are created and maintained or changed through actions of human interaction. Although it seems objective, in fact everything is built subjectively through a process of interaction. Objectivity will occur through repeated affirmations given by others who have the same subjective definition (Bungin, Bruhan, 2001).

The construction is a literal representation meaning "re-presence" of something that happened before, mediating and playing it back to describe the relationship between media texts and reality. Representation can also mean a depiction of the social world in an incomplete and narrow way. So representation is the process by which members of a culture use language to produce meaning. Language in this case is 
broadly defined, ie as any system that uses signs. The sign here can be in the form of verbal or non verbal. The understanding of the representation then has a fixed meaning or the original meaning (the true meanings) attached to him. It is the community that makes that meaningful.

Representation is a depiction of a reality, which is not an actual reality (Grossberg, 2006, 195). This concept is used to describe the expression of the relationship between ad text (media) with reality. So the representation referred to in this paper is trying to see the reality that is built in an ad creative.

Based on the background above, we intend to make a study of representations of optimism in the "Cerdikiawan" edition of Gojek advertisement. In order to do this, Roland Barthes's semiotic analysis will be used. This analysis not only functions as a method but also theory. It aims to analyze the media based on the assumption that the media are communicated through a set of signs. Three stages according to Barthes to uncover the mark in the analyzed media are; denotation stage, the stage of connotation and myth or ideology as the final stage that reflects these signs through a particular cultural point of view (Kusumastutie, 2004). Barthes' theory itself is a refinement of the theory put forward by Saussure which only discusses marking in denotative stages. Improvements made by Barthes explain in more detail about the stages of connotation.

\section{RESEARCH METHOD}

This study uses a qualitative semiotic communication method. According to Saryono (2010), this method investigates, discovers, illustrates, and explains the quality or idiosyncrasy of social influences that cannot be explained, measured, or described through quantitative methods. The object of this research is Gojek advertisement version of "Cerdikiawan" in the form of audio visual. Roland Barthes's semiotics was chosen as the research method because this method uses a two-stage interpretation system, namely denotation as the first stage and connotation as the second stage. We downloaded the 61-second advertising of Gojek "Cerdikiawan" from YouTube and analyzed it to find a representation of optimism in the ad. We also studied data from journals and other author's articles that are still related to this research.

\section{RESULTS AND DISCUSSION}

The focus of this research is on the representation of Gojek "Cerdikiawan" advertisement. This ad is a commercial advertisement that airs on mass media, especially television, and also social media. Besides being published on Youtube, this ad also often appears on Intagram and Facebook ads. In today's digital era, technology is increasingly developing and information dissemination is happening very fast. This has a significant impact on millennials, because they are the most dominant internet users in everyday life. The exposure of the media so quickly and repeatedly becomes an opportunity for the development of advertisements targeting young people. Thus, it 
is not surprising that Gojek "Cerdikiawan" ad is not only aired on television, but also on various social media.

Media plays a major role in shaping the discourse about what is ideal for the public, through advertisements that enter the most private spaces with all kinds of products. Ads are made not only to sell a product but also form the concepts, values, and image of a product. In this case, the icon in the ad becomes important. Advertising is one of the communication activities, because advertising uses the principles of communication in its manufacture. The material of a product is communicated to individuals (the public) through advertising. To evoke the image of the product being advertised, symbols are used to build the image, meaning, and awareness of a social reality.

Advertising becomes a medium for the product or service owner to convey a message to his audience. So that the message can be captured and understood by the public, advertising will provide an interpretation framework that can direct the audience to preferred reading. For this reason advertisements will inevitably use object typifications and audience realities to create meaning. The advertisement will provide the same interpretation framework as the audience's stock of knowledge, so that the ad text can be understood by the audience as desired by the advertiser. Gojek "Cerdikiawan" has a theme that tells the events that cause a problem but can be solved immediately and with the help of a makeshift tool. The ad video contains events that cause problems in daily life as well as how each scene solves its problem.

According to William's historical analysis in Fitri (2018), advertising has now become an important component for the organization and reproduction of capital. Advertising can be said to be magical. This is because advertising can present an imaginary world from a sign of glamor that is transformed by commodities. Because of its magical nature, advertising is able to hypnotize consumers to consume a commodity.

The power that is considered capable of hypnotizing consumers cannot be separated from a form of persuasive communication that is very dominant in advertising. As pointed out by Littlejohn (1992), persuasion is seen as a conscious effort to change thoughts and actions by manipulating motives toward the goals that have been set. Then it can be described that all advertisements are persuasive because advertising messages try to form, strengthen, or change perceptions, attitudes, build opinions, touch emotions or lift beliefs in the structure of beliefs.

Based on its organization in the formulation of campaign messages according to Ferguson in Ibnu Hamad (2007), there are several steps that need to be considered in composing persuasive messages, one of which is: arrangement of verbal and nonverbal symbols. These verbal and non-verbal arrangements include (1) the use of verbal and nonverbal symbols; (2) arrangement of verbal and nonverbal symbols. Psychologically, a meaning can be determined from the use and sequence of symbols (like message, like image). Then, both can also affect the effectiveness in receiving 
messages. In verbal messages, the use of certain words will produce certain meanings and images. Likewise with pictures or illustrations, the use of these two things can also produce certain meanings and images.

In composing a message, advertising is also related to the ability to develop new ideas that are fresh, unique, and reasonable; commonly used as a solution in solving a communication problem. Creative meaning in message planning is a discovery of the core message, or often called the discovery of "the big idea". Ogilvy revealed that good advertising is what sells, and good creative is what sells. So the ad cannot be said to sell if the ad is not creative. Product sales will increase if the ads are made well and in accordance with market interests (Hasto and Pambudi, 2006). In essence, Ogilvy said that an important element of marketing communication is positioning, while its mission is to be able to present advertisements that sell.

This shows that the message in the advertisement must be made very carefully. Advertisers must also consider the strategy that will be carried out, namely by considering various psychological aspects in potential customers. Thus, advertising becomes effective in influencing people's perceptions about products and services. What messages the advertiser collects can later be received and perceived equally by the public. According to Piliang (2003), logically, it is impossible for a company to spend tens to hundreds of billions of rupiah on advertising if an advertisement cannot change people's perception and desire to buy.

Advertising on television media has considerable effectiveness because in addition to being able to audio visual capabilities, television also allows message repetition. Television advertisements also reach audiences in a short time (Shimp, 2003). Therefore, it is not surprising that television is becoming a media that is increasingly in demand by advertisers to promote their products, including Gojek. This is the basis for advertising practitioners to include television as one of the media that is still used to convey information (messages) about their products. It can be assumed that advertising (mass media advertising), with its own advantages, is the most commonly used and easiest tool to see in building a brand. Advertising has the task of creating visibility, building and maintaining) brand awareness and communicating its personal brand.

According to its function, advertising has four objectives based on the target audience (Kotler, 2005). First, advertising is informative. Advertising aims to provide prospective consumers with an understanding of products made by the company. Second, advertising is persuasive because it aims to persuade or influence prospective consumers. Third, advertising aims to remind potential consumers of the company's products. The fourth, advertising aims to strengthen the message to potential customers. 


\section{Contemporary Advertising and Soft Selling}

Gojek "Cerdikiawan" is one example in the advertising world that advertising trends are developing. More contemporary advertisements appear when the industry begins to see that the target audience is not interested in hard selling ads that are too rigid and have no story. The industry is starting to change their strategy in. The industry sees opportunities in contemporary advertisements, which have more power to attract the audience to watch the advertisements until they run out because the current audience tends to prefer ads that have a story line that is interesting, out of the box, and creative. With a more contemporary type of advertising, the industry does not necessarily eliminate the product or service to be promoted. It's just that their form of promotion is no longer explicit, and is more directed to implicitly or better known as soft-selling advertisement.

This form of soft-selling contemporary advertisement is to embed symbols, symbols and signs of objects that advertisers will promote. The trick is to associate with the social life of the community that is popular so that the ad has a higher chance of being accepted by a wide audience who are not even the target audience. With a form of soft-selling promotion, Gojek's advertisement "Cleverness" deserves to be said to be very persuasive.

During this time, the social construction formed in Indonesian society is that people will not be able to do extraordinary things if they have limitations. We can see this from advertisements that show the condition of Indonesia in a sad state. There are also bad habits in Indonesia that seem lazy to try and justify any means to get what he wants. For example, in advertisements that were viral with the tagline "Wani piro". According to Andrianto et al (2019), the Djarum 76 cigarette advertisement "Wani Piro" has unique words in its presentation, giving rise to an impression of humor. However, on the other hand there is something real meaning implied in it. Social criticism is contained in these advertisements (Fatimah, 2012).

Another iconic advertisement is the 61-second version of the Aqua (drinking water product) advertisement "Tes Your Concentration and Focus ". Until 56 seconds, the audience still does not know clearly what this ad. Ads are made with suitcase search storylines, then viewers are treated to questions that focus on focus. Then at 57 seconds then the viewer knows that the ad is an Aqua product ad. Viewers are made aware of what they have missed because they lack focus.

Although they both do soft-selling, the Gojek "Clever" advertisement does something different. Gojek "Cerdikiawan" seeks to present a new social construction to the audience, both those who watch on television and Youtube. The ad is impressed to make people not give up easily and have a more creative mindset to solve existing problems.

In an effort to form a new social construction in society, this ad uses motivational and convincing texts such as "All matters can be completed". Narration like this starts from the beginning to the end of the ad. Gojek "Astdikiawan" is an 
advertisement with a contemporary idea that has the purpose of carrying out a social construction of reality in society. Gojek has infiltrated its advertisements with optimistic symbols, signs and symbols; even though the target audience is busy or experiencing difficulties in terms of transportation or other services, there are Gojek ready to help them.

\section{Representation of Optimism}

As stated earlier, the researchers agreed that Gojek's "Astdikiawan" advertising used the soft selling method. Each scene displayed in the advertisement, by denotation, is not directly related to Gojek's services. The target of this advertisement is young people from millennial. The characteristics of millennial generation itself are different from other generations. For instance, we can see their learning preferences tend toward teamwork. They also tend to do experiential activities, structure, and use technology. Their strengths include multitasking, goal orientation, positive attitudes, and collaborative style. That is what Gojek "Cerdikiawan" is trying to construct, that is, the millennial generation represents optimism.

Overall, the Gojek "Cerdikiawan" advertisement shows the daily lives of people. Various groups of people who are shown have twists and turns problems that must be faced in their lives. With their unique thinking and optimism and creativity, their problems can be solved.

Meaning connotation describes the interaction that occurs when the sign meets the feelings or emotions of the reader and the values of his culture. The connotation has subjective eating, in other words how to describe a sign (Wibowo, 2011). In each scene, the narrative that begins seems to explain to the audience about the depiction of struggles in life and an attitude of optimism. The musical instrument used in this advertisement uses the sound of a violin which makes the atmosphere more dramatic.

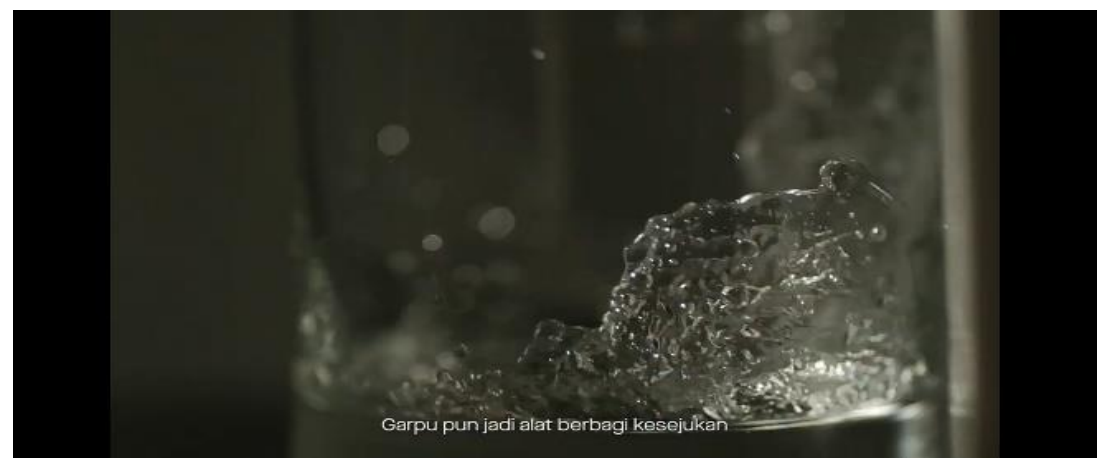

00.08

In the first scene, the meaning of denotation can be seen from the lives of office worker who has difficulty getting drinking water because of the broken dispenser lid. The man is not just silent or directly buy a new dispenser. However, he is looking for 
ways to still be able to use the dispenser. Who would have thought, a fork could be put in between the dispensers to get the water back from the dispenser.

A connotation of that indicates that a man has an optimistic nature in the face of difficulties in getting water. With a simple device around him, the fork, he can solve problems. This is supported by the narrative sentence in the advertisement "All matters can be completed, the fork becomes a tool to share coolness". In the connotation, the researcher interprets the "fork becomes a tool to sharing coolness" as a result of one's optimism. Optimism is represented by the attitude of someone who plays his wits. He then found a fork as a tool to make the dispenser function again and get drinking water that quenches thirst.

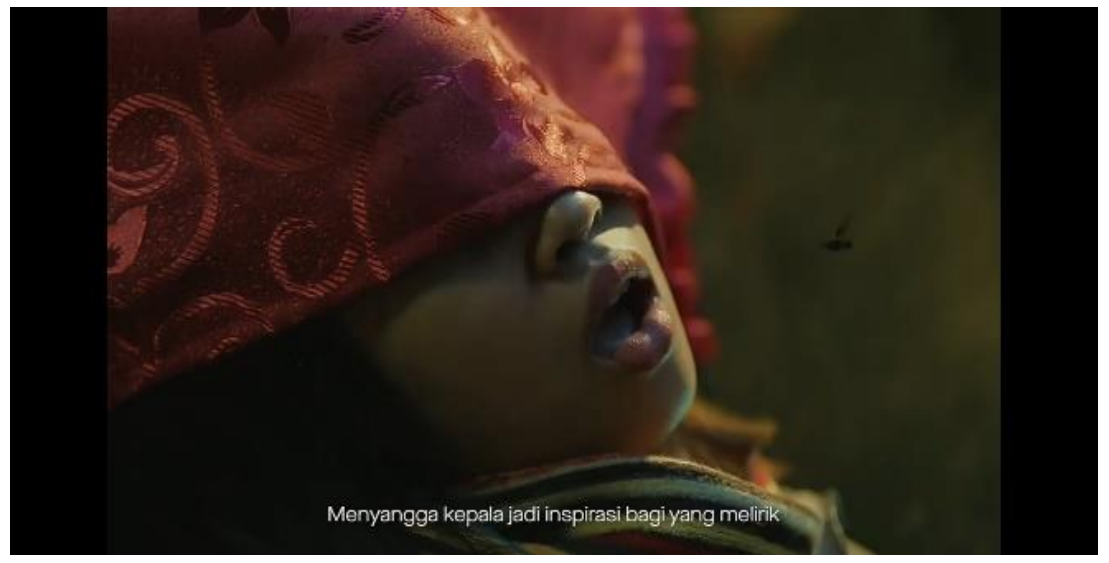

00.14

Next, there was a woman who as sleeping on the bus using a cloth as a blindfold. The woman fall asleep until her mouth is open. People around him are amazed to see that the woman sleep so soundly without caring about the surrounding conditions, even the fly stops immediately and is reluctant to enter her mouth. The narrative that appears in this scene is "Supporting the head is an inspiration for those who glance".

A woman who is sleeping with the bus seat cover in her eyes is the meaning of the denotation of this scene. Using an eye patch can make you sleep better because you are not disturbed by your surroundings. The meaning of the connotation of this scene is to sleep using a blindfold or in the dark will make you sleep more soundly. That's why he uses a chair cover to close his eyes. When people around glance with curiosity, the woman confidently tries to be optimistic so that her sleep becomes more restful. 


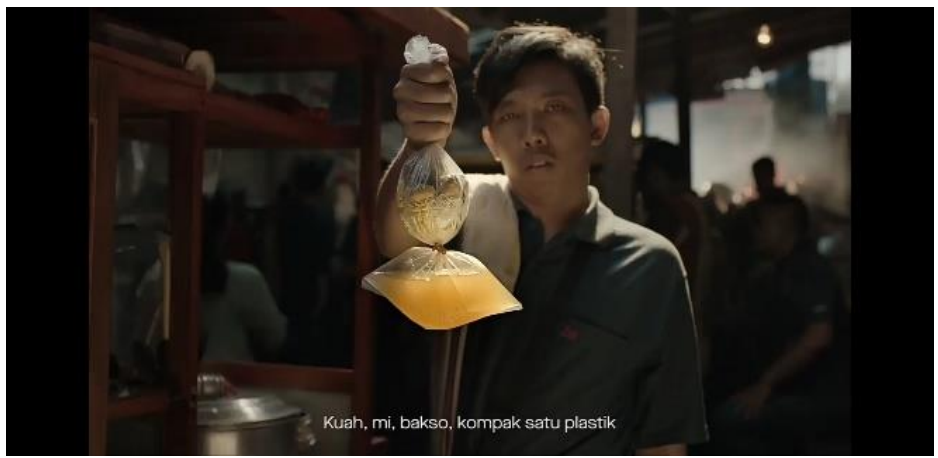

00.22

In the third scene there is a narration "Soup, noodles, meatballs, compact one plastic". Here there is the meaning of denotation that the sentence describes a meatball seller who wraps the meatball soup with the contents into one plastic bag. The connotation of the scene is that the meatball seller gets the idea to save plastic. This makes it more efficient in wrapping meatball soup and filling into one place.

An optimistic representation can be seen from the technique of using plastic to separate the sauce and stuffing meatballs. Even though he only has one plastic bag, he is able to make the meatball soup and filling separate. This is unusual, but he can do it for efficiency reasons. It can also be interpreted that in this life there are many differences between the upper and lower classes. However, that does not make them different because they are both human. Optimism to be able to live a life full of obstacles is done in a creative way that can minimize differences.

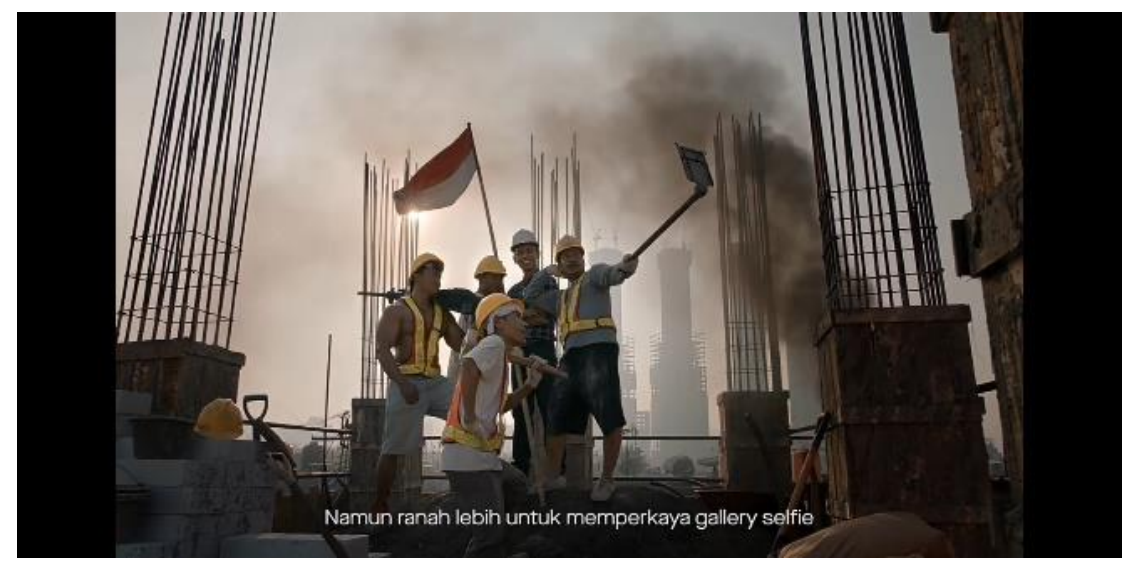

00.28

The meaning of the denotation of the next scene is depicting laborers taking selfie using a smartphone tied to the end of a hoe. The construction workers utilize the hoe as a substitute for selfie stick used for selfie. The meaning of the connotation is the narrative "Not for the sake of existence, but rather to enrich the selfie gallery" means that what they do is not intended to show off their existence to the wider world, but 
purely for their own pleasure. The thing to be shown here is that anyone has the right to do something they like and something that is popular without limitation who they are and what their job is. Even though the work is hard, they can still get style like others by taking selfie. The efforts they made using their hoe instead of selfie stick.

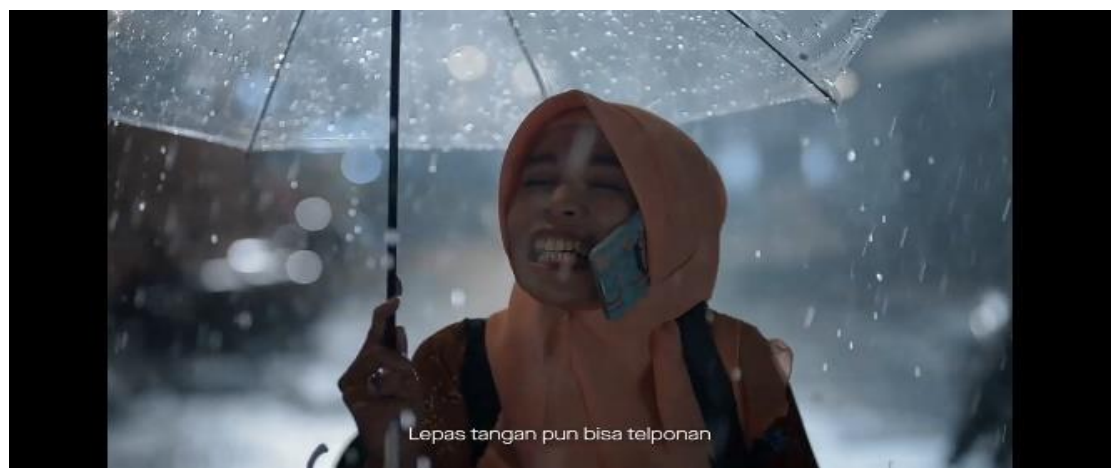

00.33

In the next scene, there is a veiled woman who is calling in the rain. Both hands are busy holding umbrella and stuffs. That is the meaning of the scene's denotation. The narration that appears to accompany the scene is "Even by letting go of the hand you can call". From there, we give connotation meaning that with an optimistic attitude, human can find unexpected ways to solve all cases. This is confirmed by a woman who seems impossible but apparently is able to do many things at once (holding an umbrella, carrying goods, bags and making phone calls). With his optimistic attitude, she then tucked his smartphone into his hijab. Thus, she can do four things at the same time.

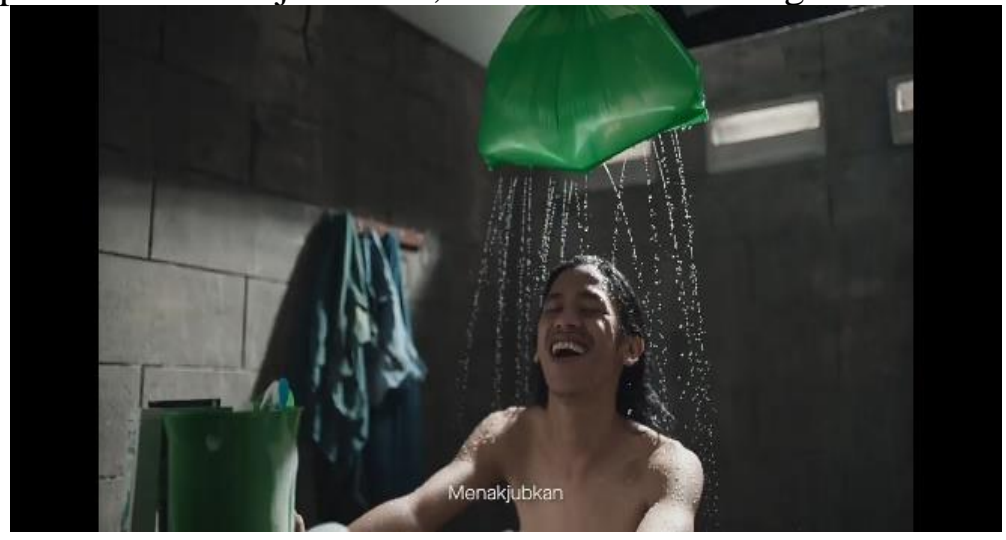

00.37

Meanwhile, a happy smile on her face can be interpreted that she feels happy with her situation. Cheerful in all conditions can also be described as an attitude of optimism because she believe that all difficulties can be endured and there is a solution. Even though it is in the rain with troublesome conditions, communication can still be done. 
In the next scene there is the word "Amazing" when it shows the scene of a man bathing in a "shower". The word continued with "Every day they water themselves with ideas". The word shower was quoted because the shower was not uncommon. In Indonesia, showers can usually be found in modern bathrooms and are made of metal or plastic. However, the man in this ad actually uses a plastic bag that is given a small hole as a substitute for a shower.

The meaning of the denotation of this scene is a man who showered with a shower made of hollow plastic bags filled with water. The connotation is that not only the rich can feel luxuriously bathing with a shower. Ordinary people can feel it too if they have extraordinary ideas. The idea is a form of optimism, where extraordinary or out of the box ideas can be used to achieve dreams or goals. Limitations are not a barrier for someone to attack the situation.

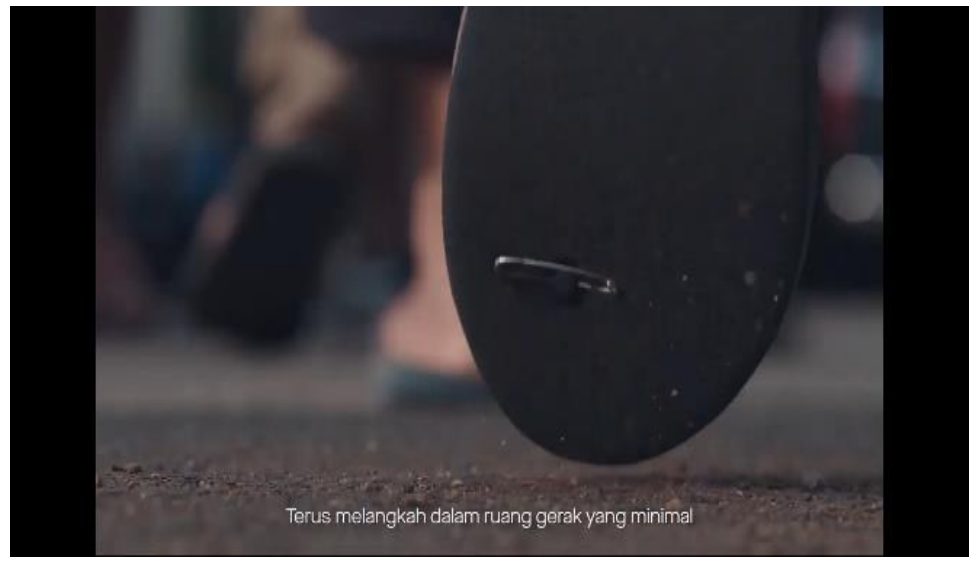

\subsection{2}

Next, there are scenes of broken sandals which are then fixed with a pin. The use of safety pins under sandals to overcome the damage is the meaning of the denotation of this scene. Meanwhile, the meaning of the connotation of the scene is that human can continue to move forward to achieve their goals. The method used may be unexpected and use minimal resources. However, it is not a problem and can keep us going. This is supported by the sentence "Continue to move with minimal space" that reinforces the meaning of the scene. 


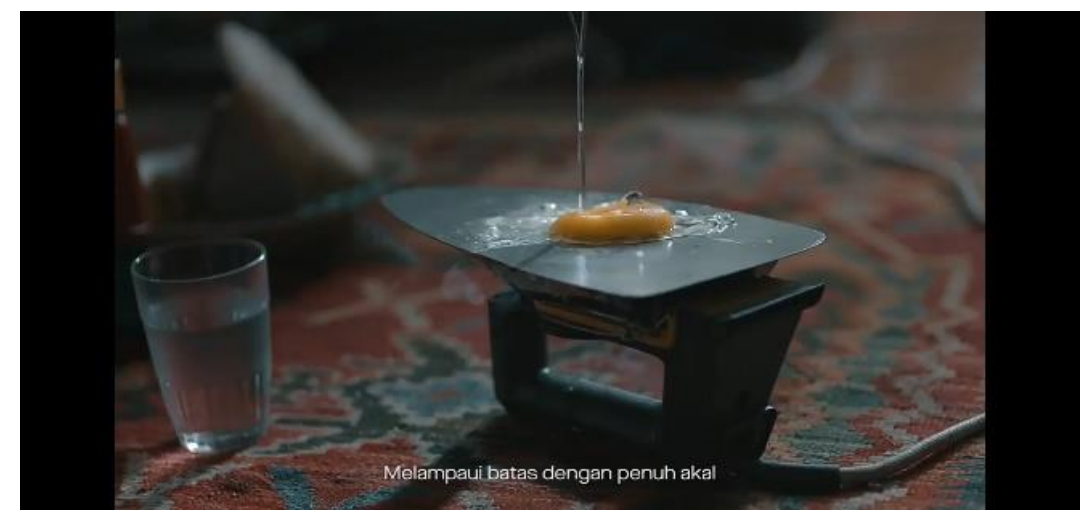

$00: 44$

Next, there is a scene of someone cooking eggs using an iron. The scene is accompanied by a narrative "Beyond the limit with full of sense". Eggs cooked using an iron are the meaning of the scene's denotation. Meanwhile, in the sense of connotation, we would not have thought that irons that are usually used to iron clothes can be used as cooking tools. Even though the man does not have a stove or other cooking utensils, he has a sense so that he can continue eating. A hot iron will be the same as a frying pan on a fire used for cooking. This shows that we can go beyond limits by using will to achieve goals. With simple capital (without cooking utensils, gas, and oil) human can get food and survive.

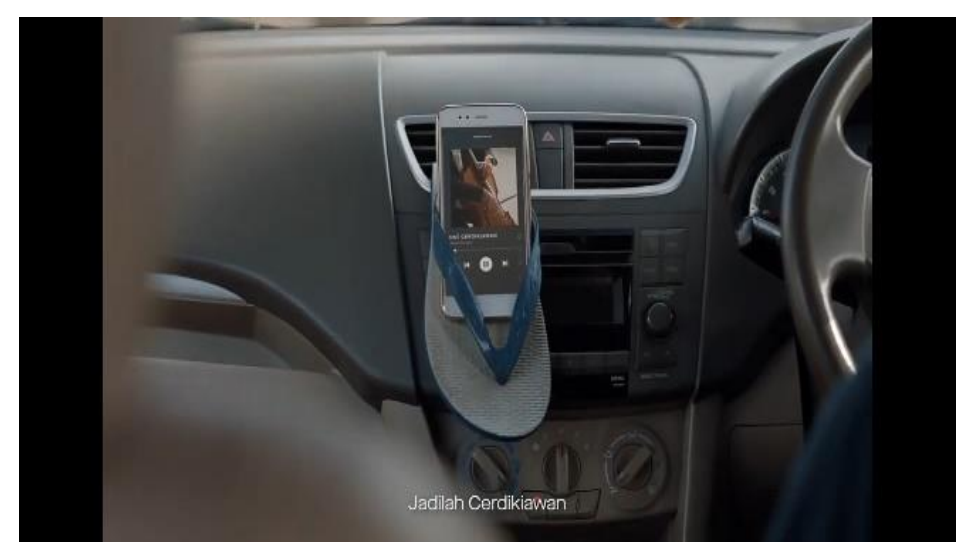

00.47

Smartphone placed on a slipper is the meaning of denotation in this scene. The smartphone is connected to the car's air conditioner as a cellphone buffer in order to play music. Then, the meaning of the connotation is that sandals can be used as a solution when the car owner does not have the tools to support the smartphone while driving. This shows the optimism of the car owner who is looking for ways that he can 
still use his cellphone in the car without buying a special tool to put a smartphone in the car. In other words, any object we can use to simplify our lives.

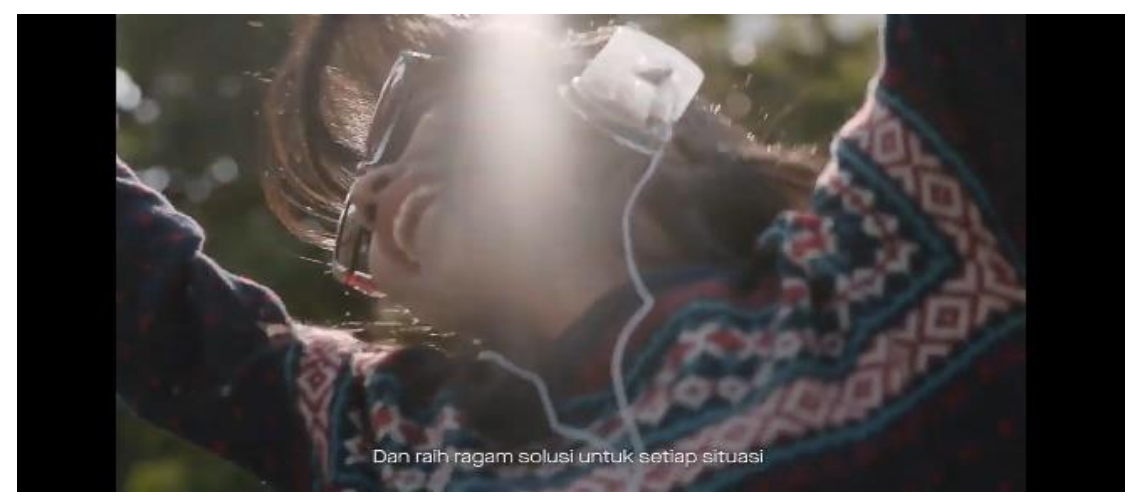

00.48

The last scene in this ad has a narration "Be smart and get a variety of solutions for each situation". This scene shows a woman who is dancing using sunglasses and earphones that are given a small plastic cup so that it functions like a headphone. This becomes the meaning of the denotation of the scene.

For the connotation meaning, she is listening to music through her own headphone. Headphone that is currently becoming a trend can be obtained through small modifications. She can still follow the trend without having to spend a lot of capital. There is a meaning that in any situation, as long as we are optimistic and use our ideas, all problems can be resolved. Gojek "Cerdikiawan" uses the hashtag \#pastiadajalan at the end of his ad to show that we must be sure that all complex situations can be overcome.

"Smart" narratives are often said in this ad. This shows that human ideas are the key to problem solving. An optimistic attitude when facing anything can overcome existing limitations.

\section{Myth in Gojek "Cerdikiawan" Advertising}

The result of this study aims to analyze the meaning of the denotation and connotation of Gojek "Cerdikiawan" advertising. Besides, it also aims to uncover the myth that is raised in the ideology implanted in the audience. The myth in this ad is that smart people tend to have a lot of sense and ideas in solving various problems. These people are described as someone who has optimism in himself.

The function of myth is to create meaning of identity and differentiation. The identity of the Gojek application, then, is represented in the final scene with the text in the form of the narrative "Like the Application of the Nation's People Work (Layaknya Aplikasi Karya Anak Bangsa)" and the tagline "There must be a way with Gojek". The differentiation in this advertisement is by using a Gojek service, audience participates 
in supporting the use of products from Indonesia. Because, Gojek is a product or work of the youth from this nation. Gojek - which is an original product of Indonesia- at the same time wants to instill a mindset of nationalism.

Gojek "Cerdikiawan" uses signs that visualize the ideology of optimism as a form of image construction for Gojek application. Exchange of symbolic signs as the delivery of messages is one of the functions of the myth. In the symbol exchange system in the "Cerfikiawan" ad, Gojek becomes a marker that has function as a sign exchange value. Gojek "Cerdikiawan" advertising has \#pastiadajalan and "There Must Be a Way" tagline. It means that Gojek wants to emphasize thought that it there will always solutions if we use Gojek application.

This ad builds meaning that optimism can be found on Gojek which can help diverse community problems. With Gojek, anything can be done. These applications can help providing an easy path for consumers. Like an optimistic and creative young generation, Gojek intends to instill optimism and creative ideas that are inspiring to the public.

\section{CONCLUSION}

Nowadays, contemporary advertisements show more creative impressions with implicit promotions. Gojek "Cerdekiawan" is a contemporary advertisement that conveys promotions implicitly by means of soft selling. The products can help solving problems in everyday life, according to the hashtag ads that are displayed namely \#pastiadajalan.

Gojek "Cerdikiawan" tries to construct optimism message to the audience. This can be seen in the meaning of denotation and connotation meaning that has been discussed by us. They all represent optimism. This ad is dominated by everyday phenomena that always have small problems that are often encountered. Each of the Gojek "Cerdikiawan" scene shows the solution of these problems with simple solutions and makeshift tools. An optimistic attitude with extraordinary ideas is the key to solving any problem. So, despite limitations, humans can still achieve their goals. This message is the core of the ad.

Meanwhile, the meaning of the myth contained in this ad is a smart and optimistic person who has a lot of idea. This is the same as the Gojek application which has many ideas for solving problems from its customers. Gojek tries to portray itself as a nationalistic and optimistic application in serving its consumers.

\section{ACKNOWLEDGMENT}

This research is made as one of the requirements for graduation Fikry Zahria Emeraldien in taking doctoral studies in Social Sciences, Faculty of Social and Political Sciences, Airlangga University, Indonesia. This research iss also made as one of the graduation requirements of Natasya Candraditya Subardja, Amalia Farahdiba, and 
Ramadhoni Cahya Candra Wibawa in Communication Studies, Faculty of Social and Political Sciences, Universitas Pembangunan Nasional (UPN) "Veteran” Jawa Timur.

\section{BIODATA}

Fikry Zahria Emeraldien is a student of Social Sciences, Faculty of Social and Political Sciences, Airlangga University, Indonesia. At present, Fikry is a lecturer at a state university in Surabaya, Indonesia, named the UPN "Veteran" Jawa Timur. Fikry teaches in the Communication Science department and has competence in the field of journalism. Email: Fikry.zahria.emeraldien-2019@fisip.unair.ac.id and fikryzahria.ilkom@fisip.upnjatim.ac.id

Other writers are Natasya Candraditya Subardja, Amalia Farahdiba, and Ramadhoni Cahya Candra Wibawa. They are currently fifth semester students of Communication Science, Faculty of Social and Political Sciences, UPN "Veteran" Jawa Timur. Natasya's email is natasyacandra12@gmail.com. Amalia's email is amaliafarahdiba@gmail.com. Ramadhoni's email is donnydonni8@gmail.com.

\section{REFERENCES}

Andrianto, T., Ariyanti, F., Prasiska, D. W., \& Prabawa, A. H. (2019). Analisis Wacana Kritis pada Iklan Rokok Djarum 76. Proceeding of The URECOL, 121-127.

Bungin, Burhan. 2001. Imaji MediaMassa, Konstruksi dan Makna realitas Sosial Iklan Televisi dalam Masyarakat Kapitalistik. Yogyakarta: Jendela.

Darley, W. K., \& Smith, R. E. (1993). Advertising claim objectivity: Antecedents and effects. Journal of Marketing, 57(4), 100-113.

Fatimah, N. (2012). Kritik sosial dalam iklan djarum 76: analisis semiotik commercial iklan djarum 76 versi "wani piro" di televisi (Doctoral dissertation, IAIN Sunan Ampel Surabaya).

FITRI, N. (2018). PESAN MORAL SIKAP PANTANG MENYERAH PADA IKLAN INDOMIE (Analisis Framing "Iklan Indomie Edisi Asian Games 2018-Satukan Tekad Indonesia (2018) Model William Gamson dan Andre Modigliani) (Doctoral dissertation, Universitas Muhammadiyah Ponorogo).

Ghufron M. Nur \& Risnawati Rini S. 2010. Teori-teori psikologi, Jogjakarta: Ar-Ruzz Media.

Grossberg, L., Wartella, E., Whitney, D. C., \& Wise, J. M. (2006). Mediamaking: Mass media in a popular culture. Sage.

Hamad, Ibnu. 2007. Perencanaan Program Komunikasi Edisi Kedua, Jakarta: Universitas Terbuka.

Hasto, P. D., \& Pambudi, T. S. (2006). Advertising That Sells. Jakarta: Gramedia.

Hasyim, M. (2014). Konstruksi Mitos dan Ideologi dalam Teks Iklan Komersial Televisi: Suatu Analisis Semiologi. Disertasi. Makassar: Program Pascarajana Universitas Hasanuddin. 
Kim, K., Hayes, J. L., Avant, J. A., \& Reid, L. N. (2014). Trends in advertising research: A longitudinal analysis of leading advertising, marketing, and communication journals, 1980 to 2010. Journal of advertising, 43(3), 296-316.

Kotler, Philip dan Amstrong, Gary. 2000. Manajemen Pemasaran, Alih Bahasa Benjamin Molan Dan Hendra Teguh, Jakarta: Edisi Milenium.

Kotler, Philip, 2005, Manajemen Pemasaran jilid 1, edisi kesebelas, Indeks, Jakarta.

Kusumastutie, N. S. (2004). Analisis Gender pada Iklan Televisi dengan Metode Semiotika. Jurnal Psikologi, (2), 130-141.

Lago, M. N. (2017). Eksploitasi Tubuh Perempuan Di Media Televisi (Analsis Semiotika Makna Pesan Iklan Cat Avian Syntetic Versi Awas Cat Basah). KINESIK, 4(2).

Littlejohn, S. W., \& Foss, K. A. (1992). Theories of human communication. 4th. Belmont: Wadsworth.

Ngangi, C. R. (2011). Konstruksi sosial dalam realitas sosial. Agri-Sosioekonomi, 7(2), $1-4$.

Nugroho, Y.K, \& Hamzah, R. E. (2018). REPRESENTASI SIKAP OPTIMISME DALAM TAMPILAN IKLAN NIVEA ME. WACANA: Jurnal Ilmiah Ilmu Komunikasi, 17(1), 105-114.

Piliang, Yasraf Amir. 2003. Hipersemiotika, Tafsir Cultural Studies Atas Matinya Makna, Yogyakarta: Jalasutra.

Saryono, A. (2010). Metodologi penelitian kualitatif dalam bidang kesehatan. Yogyakarta: Nuha Medika, 98-99.

Shimp, T. A. (2003). Advertising, Promotion and Supplemental Aspects of IMC. Pub by Harcourt Inc, New York.

Ubaedy, A. N., \& Bani, A. S. (2007). Berpikir positif: agar anda tetap pede menghadapi hidup. Bee Media Indonesia.

Wibiwo, Indiawan Seto Wahyu. 2011. Semiotika Komunikasi. Jakarta : Mitra Wacana Media.

Yuliyanti, F. D., Bajari, A., \& Mulyana, S. (2017). Representasi Maskulinitas Dalam Iklan Televisi Pond's Men \#Lelakimasakini (Analisis Semiotika Roland Bathers Terhadap Representasi Makulinitas). Jurnal Komunikasi, 9(1), 16-30. 